\title{
PENGARUH METODE LATIHAN DAN MOTIVASI BERPRESTASI TERHADAP KEMAMPUAN TEKNIK LARI 110 GAWANG PUTERA
}

\author{
*Amirzan, **M. Yahya \\ * Amirzan adalah Dosen FKIP Universitas Jabal Gafur Sigli \\ Email : amirzan_masry@yahoo.co.id \\ **M. Yahya adalah Dosen FKIP Universitas Jabal Gafur Sigli \\ Email : yahya_aka@yahoo.co.id
}

\begin{abstract}
Abstrak
Penelitian eksperimental ini bertujuan untuk mengetahui pengaruh latihan dan motivasi berprestasi terhadap kemampuan lari gawang atlet lari gawang Pengcab PASI Kabupaten Pidie Jaya. Motivasi berprestasi terbagi menjadi dua bagian yaitu tinggi dan rendah. Penelitian ini dilaksanakan di lapangan Atletik Kabupaten Pidie Jaya. Metode eksperimen menggunakan desain treatment by level 2x2. Sampel terdiri dari 52 atlet dibagi menjadi 4 kelompok, masing-masing terdiri dari 13 sampel. Teknik analisis data adalah dua-arah analisis varians (ANOVA) dan dilanjutkan dengan uji T-Tukey pada tingkat signifikan $\alpha=0.05$. Hasil penelitian ini menunjukkan bahwa (1). Secara keseluruhan, latihan pliometrik lebih baik pengaruhnya dari latihan sirkuit terhadap kemampuan teknik lari gawang pada kelompok atlet, (2) Terdapat interaksi antara metode latihan dan motivasi berprestasi terhadap kemampuan teknik lari gawang. (3) kelompok motivasi berprestasi tinggi latihan pliometrik lebih baik dari latihan sirkuit terhadap kemampuan teknik lari gawang pada kelompok motivasi berprestasi tinggi, (4) kelompok motivasi berprestasi rendah tidak berpengaruh secara signifikan, latihan sirkuit lebih baik dari latihan pliometrik terhadap kemampuan lari gawang pada kelompok motivasi berprestasi rendah.
\end{abstract}

Kata kunci: latihan pliometrik, sircuit, motivasi berprestasi

\section{PENDAHULUAN}

Undang-Undang No. 3 Tahun 2005 tentang Sistem Keolahragaan Nasional di dalamnya telah mengatur sistem pembinaan olahraga yang dilakukan melalui tiga pilar yaitu olahraga pendidikan, olahraga rekreasi dan olahraga prestasi. Hal itu dipahami bahwa pembinaan dan pengembangan olahraga di Indonesia dapat lebih difokuskan pada pembinaan dan pengembangan olahraga di daerah.

Pengembangan sarana dan prasarana yang kurang efektif dan tidak berjalan dengan baik. Program pembinaan dan pegembangan serta proses pengaturan olahraga selama ini lebih bersifat menyeluruh yang tertuju pada jajaran birokrasi di tingkat pusat, sehingga, banyak faktor yang seharusnya diharapkan bisa berjalan dengan baik sebagaimana mestinya di daerah. Kompleksitasnya cakupan permasalahan pembinaan 
olahraga oleh birokrasi pusat dalam hal ini Kemenpora, KONI pusat dan Pengurus besar menjadi tidak terpikirkan secarah utuh.

Diakui bahwa hal itu terjadi karena di semua Kabupaten yang mempunyai Pengurus Cabang (Pengcab), sehingga proses pembinaan dan pemanduan bakat pada cabang olahraga atletik yang tadinya masih belum terpusat atau masih bersifat umum dan ektra saja menjadi dipusatkan di sekolah-sekolah dan perguruan tinggi. Dan terlihat bahwa dari pengembangan program tersebut diadakannya kejuaraan Olahraga Pelajar dan atlet antara daerah dan provinsi (POPDA, POPNAS dan POMNAS) yang dilaksanakan diberbagai kabupaten dan provinsi di Indonesia.

Banyaknya persoalan yang timbul dalam pencapaian prestasi menyebabkan perlunya upaya solutif dan inovatif harus dilakukan, salah satu diantaranya dengan program pembinaan melalui penerapan metode latihan yang tepat sasaran. Agar di dalam melaksanakan program latihan sesuai dan mencapai tujuan yang diharapkan maka perlu adanya manajemen yang baik, sebab manajemen memainkan peran yang sangat penting dalam pelatihan yang sukses (Harsuki, 2012: 71)

Olahraga lari gawang merupakan nomor atletik yang selalu diperlombakan diberbagai iven keolahragaan. Lari gawang yang memiliki ciri tersendiri tentunya tidak sama dengan nomor lari jarak pendek lainnya. Ciri khas dalam lari gawang tersebut adalah tantangan berupa gawang yang harus dilewati oleh seorang pelari gawang saat melakukan lari gawang.

Kemampuan seorang pelari gawang sangat identik ketika seorang atlet melakukan lari secepat-cepatnya dengan ritme langkah yang tepat melewati rintangan gawang tanpa mengurangi kecepatan sampai pada garis finis. Penerapan metode latihan yang sesuai menjadi salah satu faktor penting untuk meningkatkan kapasistas fisik sehingga mampu melakukan latihan yang mengarah pada teknik gerakan ekplosif seperti kemampuan power otot tungkai, pinggul, punggung dan bahu serta komponen keterampilan gerak lainnya.

Metode latihan untuk meningkatkan kemampuan fisik, teknik lari gawang dengan baik banyak jenisnya seperti pliometrik, Circuit training, interval training, latihan beban (weight training). Agar metode latihan tersebut benar-benar tepat sasaran maka alangkah baiknya dilakukan pengkajian khusus secara ilmiah. Dengan demikian dapat diketahui metode latihan mana yang cocok untuk lari gawang. 
Mencermati fenomena tersebut di atas, maka peneliti mencoba melakukan kajian terhadap teknik lari gawang melalui suatu penelitian mengenai metode latihan pliometrik dan latihan sirkuit (circuit training) serta keterkaitannya dengan motivasi berprestasi. Masalah yang paling mendasar dalam penelitian ini adalah: Secara keseluruhan, Apakah terdapat perbedaan pengaruh antara metode latihan pliometrik dengan metode latihan sirkuit terhadap kemampuan teknik lari 110 meter gawang putera?, Apakah terdapat interaksi antara metode latihan dan motivasi berprestasi terhadap kemampuan teknik lari 110 meter gawang putera?, Apakah terdapat perbedaan pengaruh antara metode latihan pliometrik dengan metode latihan sirkuit terhadap kemampuan teknik lari 110 meter gawang pada kelompok motivasi berprestasi tinggi ?, Apakah terdapat perbedaan pengaruh antara metode latihan pliometrik dengan metode latihan sirkuit terhadap kemampuan teknik lari 110 meter gawang pada kelompok motivasi berprestasi rendah?

\section{Pengertian Lari Gawang}

Lari diartikan sebagai suatu gerakan berpindah tempat maju melangkah ke depan yang dilakukan lebih cepat dari pada jalan. Agar seseorang dapat melakukan lari gawang dengan baik disarankan untuk memiliki kemampuan teknik yang maksimal. Fred Mc Mane, (2008: 21) seorang pelari gawang yang baik membutuhkan konsentrasi yang kuat, kecepatan, irama, keseimbangan dan pengambilan keputusan, Menurut Djumidar, (2007: 22), waktu yang dapat dicapai ini secara keseluruhan dipengaruhi oleh dua faktor, yaitu jarak dan kecepatan rata-rata yang dapat dicapai oleh seorang pelari menempu jarak itu.

Kemampuan lari gawang adalah kemampuan lari secepat-cepatnya dengan melewari rintangan gawang. Sidik (2010: 34) mengatakan bahwa kecepatan dalam lari gawang adalah hasil kecepatan gerak dari kontraksi otot secara cepat dan kuat (powerful) melalui gerakan yang halus (smood) dan efisien (sfficient). Lari sprint gawang terdiri dari dua unsur yaitu sprint diantara gawang-gawang dan melewati gawang, dapat dirinci menjadi tahap bertolak, melewati gawang dan mendarat. Lari gawang adalah nomor lari yang diperlombakan dalam cabang atletik. Lari gawang yang diperlombakan adalah nomor 110 meter untuk putra, nomor 100 meter untuk putri dan nomor 400 meter. IAAF menjelaskan bahwa lari gawang adalah lari sprint dengan melewati rintangan (gawang) Selanjutnya Muhajir (2013: 35) menjelaskan bahwa lari gawang adalah lari cepat 
menempuh suatu jarak tertentu dengan melompati gawang-gawang yang tingginya diatur dalam peraturan perlombaan

\section{Teknik Lari Gawang}

Aip Syarifudin mengatakan (1998: 166), teknik adalah pengetahuan dan kepandaian di dalam membuat atau melakukan sesuatu kegiatan atau keterampilan gerak yang berkenaan dengan hasil dari satu cabang olahraga. Ada empat teknik dasar yang perlu dikuasai oleh pelari gawang, yaitu: 1) teknik start),2) teknik sprint menuju gawang I dan antar gawang yang terdiri dari: (a) posis badan, (b) pola langkah, (c) panjang langkah pada lari ancang-ancang/awalan, (d) Panjang langkah waktu bertolak dan waktu mendarat, dan (f) Panjang langkah antara gawang, 3) teknik lari sprint melewati gawang yakni: (a) posisi badan, (b) kaki depan, (c) kaki belakang, (d) gerak lengan tangan, dan 4) teknik sprint memasuki garis akhir finis.

\section{Kemampuan gerak}

Cabang-cabang olahraga yang menuntut kemampuan dasar yang tinggi serta keterampilan teknik yang juga tinggi dengan sendirinya membutuhkan latihan peningkatan kemampuan dasar dan latihan peningkatan keterampilan. Giri, (2013: 13-14) menjelaskan bahwa kemampuan atau keterampilan teknik merupakan hasil dari proses belajar dan berlatih gerak yang secara khusus ditujukan untuk dapat menampilkan mutu. Oleh karena itu keterampilan teknik mutu tinggi merupakan kemampuan gerak yang sangat spesifik yang menjadi suatu ciri kecabangan olahraga.

\section{Tinjauan Biomekanika}

Penguasaan teknik yang maksimal dalam lari gawang merupakan perwujudan mekanika tubuh yang berpengaruh pada efisiensi penggunaan tenaga yang mendukung pencapaian prestasi maksimal atlet. Melalui biomekanika, akan mengubah cara berpikir dogmatis ke arah berpikir ilmiah terhadap gerakan tubuh manusia, sehingga setiap mempelajari gerakan teknik cabang olahraga selalu menerapkan atas dasar prinsip-prinsip mekanika. James G. Hay, (1993: 2), biomekanika adalah mempelajari bentuk dan macam-macam gerakan atas dasar prinsip-prinsip mekanika dan menganalisis gerakan untuk dimengerti. 
Teknik lari gawang secara mekanika dapat diuraikan menjadi beberapa unsur. 1 . Start dan lari, akselerasi menuju gawang pertama;, 2. Bertolak dari gawang (tahap sangga/topang pertama), 3. Melewati/melompati gawang (tahap melayang), 4. Mendarat setelah melewati gawang (tahap topang ke dua), 5. Lari sprint di antara gawang dan 6. Lari masuk finis.

Kepentingan relatif dari unsur-unsur ini tergantung dari lombanya. Jarak lomba yang berbeda dan tinggi gawang yang digunakan menempatkan tuntutan yang berbeda kepada pelari gawang. Hasil dari suatu lomba lari gawang hanyalah ditentukan oleh faktor-faktor penentu berikut ini, 1. Start, yang digunakan adalah tidak bedanya dengan start sprint biasa, 2. Lari akselerasi, polanya tidak sama dengan lari sprint yang flat, ini ditentukan oleh penempatan gawang pertama, 3. Suatu tumpuan/tolakan eksplosif pada jarak optimum tiap-tiap gawang $(10 \mathrm{x})$, 4. Melewati gawang dengan baik dengan jalur titik grafitasi badan sedatar mungkin, 5. Suatu pendaratan setiap kali melewati gawang, yang harus aktif dan tanpa penurunan jalur titk pusat grafitasi tubuh yang signifikan, 6 . Langkah antar gawang, yang di dalam lomba lari gawang harus gesit dan cepat (fast and quick) harus dikontrol untuk menghasilkan langkah-lomba yang diinginkan, dan 7. Lari finish dengan suatu lari akselerasi akhir.

\section{Tinjauan Fisiologi}

Salah satu tujuan latihan dalam olahraga adalah untuk mencapai prestasi yang maksimal. Menurut Sukadianto, Dangsina Muluk (2010:101), untuk mencapai prestasi maksimal seseorang harus mampu melatih otot dengan baik. Tujuannya adalah meningkatkan ukuran besarnya serabut otot atau yang biasa disebut dengan hypertrophy otot. Terjadinya hypertrophy otot menurut Bompa dalam Sukadianto sebagai akibat dari: bertambahnya jumlah myofibril pada setiap serabut otot, meningkatnya densitas (kepadatan) kapiler pada setiap serabut otot, meningkatnya jumlah protein, dan bertambahnya jumlah serabut otot.

Dalam melatih adalah penting untuk melakukan berbagai proses yang behubungan dengan tujuan latihan sehingga latihan dapat berjalan sesuai rencana. Menganalisis gerakan otot tentang skill atau ketangkasan dasar atletik sangatlah menunjang pelaksanaan latihan untuk mencapai prestasi. Untuk melatih lari gawang, seorang pelatih harus tahu otot-otot yang terlibat dalam lari gawang. Dengan mengerti akan bagaimana 
otot-otot bekerja, mengenali group-group otot yang terlibat dan sistem energi apa yang terlibat dalam lari gawang barulah merencanakan program latihan dan memilih latihanlatihan khusus bagi pelari gawang.

Terjadi gerak pada tubuh manusia disebabkan karena adanya sendi atau articulasio dan musculus atau otot. Persendian adalah sebagai alat gerak pasif dan otot sebagai alat gerak aktif. Jadi bila seseorang melakukan lari gawang yang dimulai dari start, melewati gawanggawang dan sampai pada finis akan melibatkan sendi dan otot-otot sebagai alat penggerak sehingga terjadilah kontraksi otot. Terjadi kontraksi otot pada pada waktu gerakan fleksi, ekstensi, rotasio, abduksi, dan adduksi baik pada otot tungkai, badan dan lengan di dalam memproduksi gerak.

Adanya kemampuan pada seorang atlet pelari gawang ditentukan oleh masa otot pada tungkai karena anatomi tungkai cenderung lebih stabil dan susunan rangkanya yang berat sehingga perlu menyerap tenaga yang banyak selama bergerak. Dalam pelaksanaan lari sprint, melewati gawang-gawang dan sampai masuk finis, jika diamati adalah gerak yang bersumbu pada articulasio genu dan gerakannya adalah fleksi (kerut) dan ekstensi (regang) dari otot-otot dan persendian tungkai.

\section{Sistem Energi}

Terdapat dua macam sistem metabolisme energi yang diperlukan dalam setiap aktivitas gerak manusia, yaitu dari metabolisme sistem energi aerobik dan sistem energi anaerobik. Kedua sistem tersebut tidak dapat dipisahkan secara mutlak selama aktivitas kerja otot berlangsung.

Sistem anaerob selama proses pemenuhan energinya tidak memerlukan bantuan oksigen $\mathrm{O}_{2}$, namun menggunakan energi yang telah tersimpan dalam otot, yaitu ATP dan PC. Sebaliknya, sistem energi aerob dalam proses pemenuhan kebutuhan energi untuk bergerak memerlukan bantuan oksigen $\mathrm{O}_{2}$ yang diperoleh dengan cara menghirup udara yang ada disekitar dan diluar tubuh manusia melaui sistem pernapasan.

Karakteristik latihan pada sistem energi anaerobik seperti lari gawang adalah rest interval. Rest interval adalah waktu yang diberikan antara tiap set saat pelatihan untuk beristirahat. Apabila rest interval menurun atau berkurang selama pelatihan, maka dapat meningkatkan efek kardiovaskuler yang berakibat pada kegiatan sehari-hari. Satmoko (1992: 3), Rest interval adalah jeda antara set-set dalam latihan sehingga keadaan 
otot bisa dipulihkan sebagian sebelum melakukan set berikutnya.

Bompa (2000: 100), secara fisiologis penggunaan rest interval sangat menguntungkan, karena proses penyediaan energi dan kelelahan dapat teratasi. Penyediaan energi melalui lactic acid system, atau glycolysis anerobic system lebih sedikit dibandingkan melalui phosphagen system, yang berarti bahwa akumulasi asam laktat lebih kecil. Disamping itu, kandungan Adenocine Tri-Posphat

Creatine Posphat $(A T P-P C)$ yang terpakai dalam otot akan pulih kembali melalui sistem aerobik, juga terjadi pemulihan persediaan $\mathrm{O}_{2}$ myoglobin. Maka ATP-PC akan dapat digunakan kembali sebagai energi, dan sumber energi dari lactic acid system dapat dihemat, yang berarti bahwa tidak akan terjadi akumulasi asam laktat dan kelelahan dapat tertunda atau teratasi. Proses ini yang dipakai untuk meresintesi ADP dan Pi menjadi ATP dan selanjutnya akan dirubah lagi menjadi ADP + Pi yang menyebabkan terjadi pelepasan energi yang dibutuhkan untuk kontraksi otot. Perubahan $\mathrm{CP}$ ke $\mathrm{C}+\mathrm{P}$ tidak menghasilkan tenaga yang dapat dipakai untuk meresistensi ADP + Pi menjadi ATP (Edwar Fox, Bower RW: 1993: 107).

\section{Konsumsi Oksigen (VO2maks) dalam Latihan}

Suatu hal yang perlu dipahami bahwa dalam melakukan aktivitas/latihan banyak proses yang terjadi dalam tubuh. Proses tersebut antara lain adalah proses penggunaan oksigen oleh tubuh yang biasa disebut konsumsi oksigen (VO2maks). VO2 maks adalah volume maksimun oksigen yang dapat digunakan permenit.

Menurut Guyton dan Hall dalam Giri bahwa VO2 maks adalah kecepatan pemakaian oksigen dalam metabolisme aerob maksimum. VO2 maks bergantung pada kapasitas, cardiac output dan kemampuan otot untuk mengabil oksigen dari darah yang lewat. Konsumsi oksigen bagi pria dewasa pada waktu istirahat sekitar $250 \mathrm{ml} / \mathrm{menit}$. Pada keadaan maksimum, jumlah ini dapat ditingkatkan sampai pada nilai: Pria rata-rata tidak terlatih $=3600 \mathrm{ml} / \mathrm{menit}$, Pria rata-rata berlatih dalam atletik $=4000 \mathrm{ml} / \mathrm{menit}$, Pelari maraton pria $=5100 \mathrm{ml} /$ menit. Volume $\mathrm{O} 2$ maksimal adalah suatu tingkatan kemampuan tubuh yang dinyatakan dalam liter permenit atau mililiter/menit/kg berat badan. Setiap sel dalam tubuh manusia membutuhkan oksigen untuk mengubah makanan menjadi ATP (Adenosine Triphospate) yang siap dipakai untuk kerja tiap sela yang paling sedikit mengkonsumsi oksigen adalah otot dalam keadaan istirahat. Sel otot yang berkontraksi 
banyak membutuhkan ATP. Akibatnya otot yang dipakai dalam latihan membutuhkan lebih banyak oksigen dan menghasilkan CO2 Wiarto, 2013:13-14)

\section{Metode Latihan}

Siregar (210: 80), metode adalah suatu cara yang dipergunakan untuk mencapai tujuan yang telah ditetapkan. Bompa mengatakan bahwa, untuk mendapatkan hasil yang optimal dalam pembinaan olahraga dibutuhkan tiga tahapan yaitu, tahapan pengembangan multilateral, tahapan spesialisasi, dan tahapan lanjutan (advance) Aziz mengatakan bahwa metode dapat dianggap sebagai cara atau prosedur yang keberhasilannya adalah di dalam belajar atau sebagai alat yang lebih efektif. Selanjutnya Surahkmad menjelaskan bahwa metode adalah suatu cara yang di dalam fungsinya merupakan alat yang digunakan untuk mencapai tujuan. Atwi, (1997: 166) bahwa metode adalah suatu cara dalam menyajikan (menguraikan, memberi contoh, dan memberi latihan) isi pelajaran kepada siswa/objek untuk mencapai tujuan.

\section{Metode Latihan Pliometrik}

Chu (1992 : 1) mengemu-kakan bahwa metode latihan pliometrik adalah cara latihan yang dapat menghasilkan kontraksi otot menjadi kuat dengan gerakan-gerakan yang eksploslve sehingga merupakan kunci utama keberhasilan dalam seluruh aktifitas Track and field. Istilah ini sering digunakan dalam menghubungkan gerakan lompat yang berulang-ulang atau latihan reflek regang untuk menghasilkan reaksi yang eksplosive. Radcliffe dan Farentinous menyatakan latihan pliometrik adalah suatu latihan yang memiliki ciri khusus, yaitu kontraksi otot yang sangat kuat yang merupakan respons dari pembebanan dinamik atau regangan yang cepat dari otot-otot yang terlibat. Drill, pliometrik dapat dilanjutkan dengan bentuk-bentuk gerak dan kecepatan sesuai dengan penampilan cabang olahraganya. Pliometrik adalah latihan yang disusun untuk mendapatkan keuntungan dalam penyediaan dan penggunaan tenaga pada tubuh melalui lingkaran memanjang dan memendek otot, ini tergantung faktor physiologis, bahwa otot dapat lebih dipacu jika peregangan secara aktif sebelum menjadi pendek, hal ini akan meningkatkan toleransi otot dan meningkatkan peregangan.

Berdasarkan serabutnya ada dua jenis otot rangka yang ada dalam tubuh manusia yaitu; 1) otot putih (otot kontraksi cepat). Otot putih ini menurut beliau memeliki 
karakteristik bekerja secara anaerobic, intensitasnya tinggi, mudah mencapai kelelahandan kontraksinya dua kali lipat lebih kuat. Konsumsi energi berasal dari glikolisis. Otot putih ini banyak terdapat pada otot yang digunakan untuk beraktivitas yang kuat dan berat. Contohnya ketika melakukan sprint 100 meter. 2) otot merah (otot kontraksi lambat). Otot ini disebut otot merah karena banyak mengandung haemoglobin. Otot ini memiliki karakteristik bekerja secara aerobic, tidak mudah lelah, kontraksinya lambat, aktivitasnya memerlukan waktu yang lama serta mengandung haemoglobin dan enaim oksidasi.

Radcliffe dan Farentinos membagi tiga kelompok latihan pliometrik, yaitu:

a) Latihan untuk anggota gerakan bawah (pinggul dan tungkai), meliputi: loncat lambung, loncat-loncat, lompat langkah, lompat pantul.

b) Latihan untuk otot batang tubuh, meliputi: melenting, mengayun, memutar, menekuk.

c) Latihan untuk anggota gerak atas, meliputi: menekan, mengayun, melempar.

\section{Metode Latihan Sirkuit}

Metode Latihan Sirkuit Training pertama kali diperkenalkan Morgan dan Adams pada tahun 1953 di Universitas Of Leeds di Inggris. Walaupun latihan sirkuit sudah cukup lama dikenal namun sampai saat ini masih dianggap sebagai suatu bentuk latihan yang masih terus menjadi pilihan oleh para pelatih olahraga.

Tangkudung (2012: 68) mengatakan bahwa latihan sirkuit adalah salah satu cara memperbaiki secara serempak tingkat fitness keseluruhan dari tubuh kita meliputi komponen biomotorik dasar Dengan demikian dapat dipahami bahwa latihan sikuit merupakan latihan yang dilakukan dengan tujuan meningkatkan kemampuan fisik yang dilakukan berdasarkan sistem pos atau stasiun, setiap stasiun atlet melakukan gerakan tertentu yang berhubungan dengan komponen fisik yang akan ditingkatkan berdasarkan tujuan latihan.

Pelaksanaan sirkuit training adalah dalam suatu daerah atau pos tertentu setiap atlit diharuskan melakukan latihan tertentu. Latihan tersebut dapat berbentuk latihan physical conditioning (bisa tanpa alat atau dengan mempergunakan alat) Dalam proses pelaksanaannya latihan serkuit senantiasa mengarahkan atlet yang sedang berlatih 
berpindah dengan bebas setelah menyelesaikan tugas dari pos awal ke pos berikutnya sampai selesai pos-pos itu dikunjungi selama satu putaran (ronde).

\section{Motivasi Berprestasi}

Malik, (2004: 158). Motivasi adalah Perubahan energi dalam diri (peribadi) seseorang yang ditandai dengan timbulnya perasaan dan reaksi untuk mencapai tujuan. Jamaris (2010: 238) mengatakan bahwa motivasi dapat didefinisikan sebagai suatu tenaga yang mendorong dan mengarahkan perilaku manusia untuk mencapai tujuan yang akan dicapainya. Motivasi adalah suatu kekuatan atau tenaga yang membuat individu bergerak dan memilih untuk melakukan suatu kegiatan dan mengarahkan kegiatan terasebut ke arah tujuan yang akan dicapainya.

Motivasi dapat juga dikatakan serangkaian usaha untuk menyediakan kondisikondisi tertentu, sehingga seseorang mau dan ingin melaksanakan sesuatu, dan bila ia tidak suka, maka akan berusaha untuk meniadakan atau mengelakkan perasaan tidak suka itu. Jadi motivasi itu dapat dirangsang oleh faktor dari luar tetapi motivasi itu adalah tumbuh di dalam diri seseorang. Djamarah (2011: 149-151) mengatakan bahwa motivasi itu terdiri dari motivasi yang berasal dari dalam diri peribadi seseorang yang disebut "motivasi instrinsik yaitu motif-motif yang menjadi aktif atau berfunginya tidak perlu dirangsang dari luar karena dalam setip diri inividu sudah ada dorongan untuk melakukan sesuatu, dan motivasi yang berasal dari luar diri seseorang yang disebut "motivasi ekstrinsik" yaitu kebalikan dari motivasi instrinsik. Motivasi adalah motif-motif yang aktif dan berfungsi karena adanya rangsangan luar.

Komaruddin: (2013: 24) menegaskan bahwa motivasi dapat didefinisikan sebagai dorongan yang berasal dari dalam atau dari luar diri individu untuk melakukan suatu aktivitas yang bisa menjamin kelangsungan aktivitas tersebut, serta dapat menentukan arah, haluan dan besaran upaya yang dikerahkan untuk melakukan aktivitas sehingga dapat mencapai tujuan yang telah ditetapkan.

Santrock (2007: 510) mengatakan bahwa motivasi adalah proses memberi semangat, arah, dan kegigihan perilaku. Artinya perilaku yang termotivasi adalah perilaku yang penuh energi, terarah dan bertahan lama. Kemudian.

Dengan demikian maka motivasi merupakan sesuatu dorongan yang terwujud dalam tingkah laku, aktivitas dan kegiatan dengan sungguh-sungguh untuk mencapai 
tujuan yang diharapkan. Komunikasi sikap antara pelatih dan atlet memiliki suatu dampak yang sangat nyata di dalam melahirkakan motivasi latihan yang besar kepada atlet untuk mencapai prestasi maksimal.

\section{METODOLOGI PENELITIAN}

Penelitian ini dilaksanakan di Pengcab PASI Kabupaten Pidie Jaya. Waktu penelitian selama 4 bulan dengan rincian pelaksanaan sebagai berikut: 1. Bulan pertama persiapan pelaksanaan penelitian yang terdiri dari persiapan sampel dan uji coba istrumen, 2. Bulan kedua pengambilan data motivasi berprestasi dan penyusunan program, 3. Bulan ketiga dan keempat pelaksanaan perlakuan.

\section{Metode dan Desain Penelitian}

Metode yang digunakan dalam penelitian ini adalah metode eksperimen lapangan dengan desain treatment by level $2 \times 2$.

\begin{tabular}{|c|c|c|c|}
\hline & & Metode & ihan $(A)$ \\
\hline Met & $\begin{array}{l}\text { e Latihan } \\
\text { estasi }\end{array}$ & $\begin{array}{l}\text { Pliometrik } \\
\text { (A1) }\end{array}$ & Sirkuit (A2) \\
\hline Motivasi & $\begin{array}{c}\text { Tinggi } \\
\text { (B1) }\end{array}$ & A1B1 & $\mathrm{A} 2 \mathrm{~B} 1$ \\
\hline (B) & $\begin{array}{c}\text { Rendah } \\
\text { (B2) }\end{array}$ & $\mathrm{A} 1 \mathrm{~B} 2$ & $\mathrm{~A} 2 \mathrm{~B} 2$ \\
\hline
\end{tabular}

Sampel dalam penelitian didapat dari populasi terjangkau yaitu atlet putra sebanyak 96 orang. Total populasi target didasarkan pada pertimbangan atlet yang belum memilki keterampilan teknik dasar lari gawang. Dari 96 orang yang mengikuti tes motivasi berprestasi untuk mengetahui motivasi berprestasinya selanjutnya data disusun berdasarkan skor tertinggi ke terendah.

Kemudian menentukan kelompok yang mewakili motivasi berprestasi tinggi dan kelompok mewakili motivasi berprestasi rendah, menggunakan teknik prosentase yaitu $27 \%$ untuk batas atas dan $27 \%$ untuk batas bawah. Sehingga didapat jumlah sampel masing-masing 26 sampel untuk kelompok motivasi tinggi dan 26 untuk kelompok motivasi rendah. Untuk menentukan 13 orang sampel pada setiap kelompok sel dilakukan 
dengan cara diundi. Dari itu didapatkan 13 sampel untuk A1B1, 13 sampel untuk A2B1 dan 13 sampel untuk A2B1, 13 sampel untuk A2B2.

\section{Teknik Pengumpulan dan Analisis Data}

Teknik pengumpulan data mengacu pada variabel-variabel yang diteliti yaitu data tentang kemampuan teknik lari gawang dan data tentang motivasi berprestasi.Data yang terkumpul dalam penelitian ini dianalisis dengan statistik. Sesuai dengan desain penelitian eksperimental data yang diperoleh melalui tes kemampuan motorik, uji homogenitas dengan uji Bartlett.

Apabila datanya normal dan homogen maka, dilanjutkan dengan analisis parametrik dengan teknik analisis varians (ANAVA) dua jalur dengan taraf signifikan $\alpha 0,05$. Apabila dalam uji anava terdapat pengaruh yang signifikan dari setiap faktor perlakuan dan interaksinya, dilanjutkan dengan uji T-Tukey. Akan tetapi sebelum diolah data yang terkumpul, terlebih dahulu uji persyaratan dalam hal ini uji normalitas data, menggunakan Uji Lilifors.

\section{Pengujian Hipotesis}

Dengan terujinya normalitas dan homogenitas data hasil penelitian, maka syarat untuk analisis varians (ANAVA) telah terpenuhi). Pengujian hipotesis menggunakan analisis varians $(A N A V A)$ dua arah merujuk pada Sudjana.

Tabel Rangkuman Hasil ANOVA

\begin{tabular}{|l|c|c|c|c|c|c|}
\hline \multicolumn{1}{|c|}{$\begin{array}{c}\text { Sumber } \\
\text { Varians }\end{array}$} & \multirow{2}{*}{$\mathrm{JK}$} & \multirow{2}{*}{$\mathrm{Db}$} & \multirow{2}{*}{$\mathrm{RJK}$} & \multirow{2}{*}{ Fhitung } & \multicolumn{2}{c|}{ Ftab } \\
\cline { 6 - 8 } & & & & & $\alpha=0,05$ & $\alpha=0,01$ \\
\hline Antar (A) & 1065,66 & 1 & 1065,658 & 4,7631 & 3,17 & 5,06 \\
\hline Antar (B) & 843,67 & 1 & 843,6684 & 3,7709 & 3,17 & 5,06 \\
\hline $\begin{array}{l}\text { Interaksi } \\
\text { (AxB) }\end{array}$ & $\begin{array}{c}1210,84 \\
7\end{array}$ & 1 & 1210,847 & 5,4121 & 3,17 & 5,06 \\
\hline & 10739,0 & & & & & \\
Dalam & 7 & 48 & $\mathbf{2 2 3 , 7 3 0 7}$ & - & - & - \\
\hline Total & 13859,2 & 51 & - & - & - & - \\
\hline
\end{tabular}

Berdasarkan tabel di atas dapat dijelaskan sebagai berikut :

\section{Perbedaan hasil kemampuan lari gawang antara metode latihan pliometrik dan metode latihan sirkuit.}

Berdasarkan hasil perhitung-an uji t-tukey, dapat dilihat bahwa thitung $=2,182$, ternyata lebih besar dari pada $t_{\text {tabel}}$, yaitu sebesar 2,006 $\left(t_{\text {hit }}=2,182>t_{\text {tab }}=2,006\right)$, 
sehingga $\mathrm{H}_{0}$ ditolak dan $\mathrm{H}_{1}$ diterima. Dengan demikian dapat disimpulkan bahwa secara keseluruhan terdapat perbedaan pengaruh yang signifikan antara metode latihan pliometrik dengan metode latihan sirkuit terhadap hasil kemampuanlari gawang pada cabang olahraga atletik. Dengan kata lain bahwa hasil kemampuan lari gawang menggunakan metode latihan pliometrik ( $\bar{X}=105$ dan sd =16,98) lebih baik daripada hasil kemampuan lari gawang menggunakan metode latihan sirkuit $(\bar{X}=95$ dan $\mathrm{s}=$ 14,94). Berarti hipotesis penelitian pertama yang menyatakan bahwa secara keseluruhan hasil kemampuan lari gawang dengan menggunakan metode latihan pliometrik lebih baik dibandingkan dengan metode latihan sirkuit teruji.

\section{Interaksi antara metode latihan dengan motivasi berprestasi terhadap hasil kemampuan lari gawang.}

Berdasarkan hasil analisis varians, diperoleh harga $F_{\text {hitung }}$ interaksi $(\mathrm{FAB})=5,412$ dan $F_{\text {tabel }}=3,17$, tampak bahwa $F_{\text {hitung }}>F_{\text {tabel }}$, sehingga hipótesis nol $\left(\mathrm{H}_{0}\right)$ yang menyatakan tidak ada interaksi antara metode latihan dan motivasi berprestasi terhadap hasil kemampuan lari gawang ditolak dan hipótesis alternatif $\left(\mathrm{H}_{1}\right)$ diterima. Dengan kata lain dapat dinyatakan bahwa pencapaian tingkat kemampuan lari gawang dipengaruhi adanya interaksi antara metode latihan dan motivasi berprestasi.

Berdasarkan data hasil penelitian, diperoleh skor rata-rata kemampuan lari gawang kelompok motivasi berprestasi tinggi yang dilatih dengan metode latihan pliometrik adalah sebesar 113 dan kelompok motivasi berprestasi rendah adalah sebesar 96. Untuk skor rata-rata kemampuan lari gawang kelompok motivasi berprestasi tinggi yang dilatih dengan metode latihan sirkuit adalah sebesar 95 dan kelompok motivasi berprestasi rendah adalah sebesar 96.

Dengan demikian hipotesis penelitian kedua yang menyatakan terdapat interaksi antara metode latihan dan motivasi berprestasi terhadap kemampuan lari gawang pada cabang olahraga atletik teruji.

\section{Perbedaan hasil kemampuan lari gawang antara metode latihan pliometrik dan metode latihan sirkuit bagi kelompok Motivasi berprestasi tinggi.}

Berdasarkan hasil analisis, menunjukkan bahwa harga $t_{\text {hitung }}\left(t_{h}\right)=3,743$ lebih besar daripada $t_{\text {tabel }}=1,67$ atau $t_{\text {hitung }}>t_{\text {tabel }}$ pada taraf signifikan $\alpha 0.05$, dengan demikian hipotesis nol $\left(\mathrm{H}_{\mathrm{o}}\right)$ ditolak dan hipotesis alternatif $(\mathrm{H} 1)$ diterima, artinya, bahwa hasil 
kemampuan lari gawang bagi kelompok motivasi berprestasi tinggi yang dilatih dengan metode latihan pliometrik $(\bar{X}=113$ dan $\mathrm{s}=14,03)$ lebih tinggi daripada yang dilatih dengan metode latihan sirkuit $(\bar{x}=95$ dan $\mathrm{s}=15,38)$. Hal ini berarti hipotesis penelitian kedua yang menyatakan bahwa untuk motivasi berprestasi tinggi, metode latihan pliometrik lebih tinggi dibandingkan dengan metode latihan sirkuit terhadap hasil kemampuan lari gawang teruji.

\section{Perbedaan hasil kemampuan lari gawang antara metode latihan pliometrik dan metode latihan sirkuit bagi kelompok motivasi berprestasi rendah.}

Perhitungan analisis varians tahap lanjut dengan uji T-Tukey untuk membandingkan kelompok motivasi berprestasi rendah kedua metode eksperimen juga merujuk pada pendapat Gane V. Glass. Perhitungan mengenai perbedaan pengaruh kemampuan lari gawang bagi kelompok motivasi ber-prestasi rendah yang dilatih dengan metode sirkuit dan pliometrik (P4 : P3)

Berdasarkan hasil analisis, menunjukkan bahwa harga $t_{\text {hitung }}\left(t_{h}\right)=-0,337$ lebih kecil daripada $t_{\text {tabel }}=1,67$ atau $t_{\text {hitung }}<t_{\text {tabel }}$ pada taraf signifikan $\alpha 0.05$, dengan demikian hipotesis nol $\left(\mathrm{H}_{\mathrm{o}}\right)$ diterima dan hipotesis alternatif $(\mathrm{H} 1)$ ditolak, artinya, bahwa hasil kemampuan lari gawang bagi kelompok motivasi berprestasi rendah yang dilatih dengan metode latihan sirkuit $(\bar{X}=96$ dan $\mathrm{s}=15,3)$ dan yang dilatih dengan metode latihan pliometrik ( $\bar{X}=96$ dan s $=15,07)$ tidak mem-perlihatkan perbedaan yang signifikan pada $\operatorname{taraf} \alpha: 0,05$. Hal ini berarti hipotesis penelitian keempat yang menyatakan bahwa; untuk motivasi berprestasi rendah, metode latihan sirkuit lebih baik dibandingkan dengan metode latihan pliometrik terhadap hasil kemampuan lari gawang tidak teruji. Dengan demikian latihan sirkuit lebih baik daripada latihan pliometrik pada kelompok motivasi rendah.

\section{PEMBAHASAN HASIL PENELITIAN}

1. Perbedaan hasil kemampuan lari gawang antara metode latihan pliometrik dan metode latihan sirkuit

Hasil pengujian hipotesis pertama, membuktikan bahwa secara keseluruhan atlet yang berlatih dengan metode latihan pliometrik lebih tinggi hasilnya dibandingkan dengan atlet yang berlatih dengan metode latihan sirkuit. Dalam hal ini dapat dinyatakan 
bahwa untuk mencapai tujuan, metode latihan pliornetrik lebih efektif dibanding dengan metode latihan sirkuit.

Efektifitas metode latihan pliometrik dalam latihan, tidak terlepas dari hal-hal seperti; secara teori metode latihan pliometrik lebih baik dari metode latihan sirkuit. Gerakan-gerakan pada kemampuan lari gawang merupakan gerakan yang dinamis serta dirangkai menjadi suatu rangkaian gerak lebih cocok dengan kemampuan gerak motorik yang dimiliki atlet. Pada prinsipnya motivasi berprestasi adalah yang berisikan kekuatan, kecepatan, kelenturan, keseimbangan, kelincahan serta koordinasi sehingga dapat berkontribusi dengan rangkaian gerak yang ada pada lari gawang.

Metode latihan pliometrik adalah metode latihan yang mengarah pada pencapaian tujuan latihan lari gawang secara efisien, yaitu menguasai kemampuan melalui pengembangan gerakan dengan cepat dan dinamis sesuai dengan tujuan latihan. Disamping itu, pada pemberian latihan lari gawang atlet diarahkan kepada latihan yang bertumpu pada pengembangan dan pengayaan gerak sehingga titik berat pemberian latihan adalah penguasaan kemampuan dan ketangkasan gerak.

\section{Interaksi antara metode latihan dan motivasi berprestasi terhadap kemampuan gari gawang}

Hasil pengujian hipotesis yang dilakukan membuktikan bahwa ada interaksi antara metode latihan dan motivasi berprestasi terhadap kemampuan lari gawang. Kelompok atlet yang mempunyai motivasi berprestasi tinggi dan diberi metode latihan pliometrik hasil kemampuan lari gawang lebih tinggi dibandingkan dengan kelompok atlet yang memiliki motivasi berprestasi tinggi yang diberi metode latihan sirkuit. Hal ini menunjukkan bahwa kontribusi pendekatan metode latihan berhubungan dengan karakteristik atlet yang mengikuti pemberian latihan lari gawang.

Pada kelompok atlet yang memiliki motivasi berprestasi rendah yang berlatih dengan metode latihan pliometrik dan metode latihan sirkuit tidak memberikan perbedaan hasil kemampuan lari gawang. Hal ini juga menunjukkan bahwa kontribusi metode latihan pliometrik dan metode latihan sirkuit sama-sama berhubungan dengan karakteristik atlet yang mengikuti pemberian latihan.

Efektifitas pendekatan metode latihan pada kelompok atlet yang memiliki motivasi berprestasi tinggi, terkait dengan sifat subjek atlet dan model interaksi latihan yang tercipta oleh metode latihan pliometrik itu sendiri. Atlet yang memiliki motivasi 
berprestasi tinggi mempunyai sifat lebih mandiri (independen), dalam melakukan kegiatan pemberian latihan seperti mengikuti pemberian latihan, mendengarkan informasi, membaca rangkaian gerak serta melakukan latihan ataupun eksperimen, dan sebagainya.

Pada atlet yang memiliki motivasi berprestasi rendah, penggunaan metode latihan sirkuit dalam latihan lari gawang mencapai hasil yang lebih tinggi jika dibandingkan dengan penggunaan metode latihan pliometrik. Hal ini memberikan pemahaman bahwa bagi atlet yang mempunyai motivasi berprestasi rendah, terkait dengan sifat subjek atlet dan pendekatan interaksi metode latihan itu sendiri. Atlet yang memiliki motivasi berprestasi rendah suka melakukan kegiatan seperti, mengikuti pelajaran, mendengarkan informasi, membaca gerakan, mengamati serta melakukan latihan, dengan petunjuk dan bimbingan pelatih. Dalam aktifitas berlatih mereka suka menerima koreksi dari pelatih atas kesalahan yang dilakukan.

\section{Perbedaan hasil kemampuan lari gawang antara metode latihan pliometrik dan metode latihan sirkuit kelompok motivasi ber-prestasi tinggi.}

Hasil pengujian hipotesis ketiga membuktikan bahwa atlet yang memiliki motivasi tinggi yang dilatih dengan metode latihan pliometrik lebih tinggi hasilnya dibandingkan dengan atlet yang dilatih dengan metode latihan sirkuit. Dalam hal ini dapat dikatakan bahwa untuk mencapai kebehasilan sebagai tujuan dalam latihan, metode latihan pliornetrik lebih efektif dibanding dengan metode latihan sirkuit dalam meningkatkan kemampuan teknik lari gawang.

Motivasi merupakan unsur yang mengadung kemauan untuk melakukan usaha untuk mencapai tujuan tertentu. Dalam kaitannya dengan penelitian ini adalah melakukan latihan untuk dapat menguasai teknik lari gawang sehingga keberhasilan atlet dalam melakukan lari gawang dengan baik dapat tercapai. Dengan demikian memiliki motivasi berprestasi tinggi yang berisikan kekuatan, kecepatan, kelenturan, keseimbangan, kelincahan serta koordinasi dapat dikembangkan melalui latihan pliometrik dapat berkontribusi yang lebih besar lagi terhadap rangkaian gerak yang ada pada kemampuan lari gawang.

Metode latihan pliometrik adalah salah satu metode latihan yang menitik beratkan pada pengayaan gerak yang dinamis, cepat dan kuat, membutuhkan kontraksi otot putih yang bisa melahirkan daya ledak yang eksplosif. Metode latihan ini mengarah pada 
pencapaian tujuan lari gawang secara efisien, yang menuntut penguasaan kemampu-an teknik melalui pengembangan gerakan dengan cepat dan dinamis sesuai dengan tujuan latihan.

\section{Perbedaan hasil kemampuan lari gawang antara metode latihan pliometrik dan metode latihan sirkuit kelompok motivasi berprestasi rendah}

Hasil pengujian hipotesis membuktikan bahwa atlet yang memiliki motivasi berprestasi rendah yang dilatih dengan metode latihan pliometrik lebih rendah hasilnya dibandingkan dengan atlet yang dilatih dengan metode latihan sirkuit. Dengan demikian metode latihan sikuit lebih baik dibandingkan dengan metode latihan pliomertik pada atlet motivasi berprestasi rendah.

\section{KESIMPULAN}

Berdasarkan hasil analisis data, hasil pengujian hipotesis dan hasil pembahasan penelitian, maka dapat dijabarkan sebagai berikut:

1). Secara keseluruhan, teknik lari gawang melalui penerapan metode latihan pliometrik lebih baik dibandingkan dengan metode latihan sirkuit.

2). Terdapat interaksi antara metode latihan dengan motivasi berprestasi terhadap hasil kemampuan teknik lari gawang .

3). Bagi atlet yang memiliki tingkat motivasi berprestasi tinggi, hasil kemampuan teknik lari gawang melalui penerapan metode latihan pliometrik lebih baik dibandingkan dengan metode latihan sirkuit.

4). Bagi atlet yang memiliki tingkat motivasi berprestasi rendah, hasil kemampuan teknik lari gawang melalui penerapan metode latihan pliometrik dan metode latihan sirkuit tidak memberikan perbedaan yang signifikan.

\section{DAFTAR PUSTAKA}

- Bompa. Tudor O, Periodization, Theory and Methodology of Training, Ed. Dubuque: Kendal/Hunt Publishing Company.2000

- Bompa. Tudor O, Theory and Methodology of Training Dubuque IOWA: Kendal Hunt Pub. Camp, 2009

- Chu Donald, Jumping into Plyometrics, Other Sport Injuri Clenic Castro Valley, 1992

- Yulinar, Y. and Kurniawan, E., 2018. PENGARUH LATIHAN RENANG TERHADAP PENINGKATAN DAYA TAHAN KARDIOVASKULER PADA ATLET KLUB SEPAK BOLA. JURNAL SERAMBI ILMU, 30(2), pp.88-103. 
- Dauyah, E. and Yulinar, Y., 2018. Faktor-Faktor Yang Mempengaruhi Motivasi Belajar Bahasa Inggris Mahasiswanon-Pendidikan Bahasa Inggris. JURNAL SERAMBI ILMU, 30(2), pp.196-209.

- Israwati, I., 2018. Pengaruh Strategi Pembelajaran Dan Motivasi Mengajar Guru Terhadap Hasil Belajar Siswa. Jurnal Serambi Ilmu, 19(2), pp.65-124.

- Didik Zafar Sidik, Mengajar dan Melatih Atletik, Bandung : PT Remaja Rosdakarya, 2010

- Djumidar, Dasar-Dasar Atletik, Jakarta : Depdiknas UT, 2007

- Harsono, Coching dan aspek-aspek psikologis dalam coaching, Jakarta: CV Tambak Kusuma 1988.

- Harsuki, Pengantar Manajemen Olahraga. Jakarta: Rajawali Pers, 2012.

- IAAF, Kurikulum Level I dan II, Materi Penataran pelatih, Jakarta: PASI, 2001

- Jamaris Martini, Orientasi Baru dalam Psikologi Pendidikan, Jakarta Pusat: Yayasan Penamas Murni, 2010

- Komarudin dan Yusuf Hidayat, Psikologi Olahraga. Latihan Mental dalam Olahraga Kompetitif. Bandung; PT Remaja Rosdakarya

- Oemar Malik, Proses Belajar Mengajar, Jakarta: PT Bumi Aksara. 2004

- Sanjaya Wina, Strategi Pembelajara Berorientasi Standar Proses Pendidikan, Jakarta : Kencana Prenadamedia, 2013

- Santrock John W, Psikologi Pendidikan Jilid 2, Jakarta:Kencana. 2000

- Gunarsa D. Singgih. Psikologi Olahraga Prestasi, Jakarta: Gunung Mulia. 2008

- Surahkmad Winarno, Pengantar Penelitian Ilmiah, Bandung :Tarsito, 2004

- Undang-Undang, Sistem Keolahragaan Nasional, Jakarta: Biro Humas dan Hukum, Kementrian Pemuda dan Olahraga RI, 2008. 